\title{
Syrian Senior Dental Students' Perception, Educational Satisfaction, and Attitude Regarding the Usage of Rubber
} Dam

\author{
Louai MF Younes ${ }^{1}$, Mazen Doumani ${ }^{2}$, Talal F Al-Nahlawi ${ }^{3}$, Abdulaziz S Alharbi ${ }^{4}$, Adnan Habib $^{5}$
}

\begin{abstract}
Aim: The study aimed to determine the perception, educational satisfaction, and attitude of dental students (fourth and fifth years) regarding the usage of rubber dam.

Materials and methods: A piloted questionnaire was distributed to fourth- and fifth-dental students in Damascus (governmental) and Syrian private (private) dental schools in August 2019. Information collected included perception, educational satisfaction, and attitude to the usage of rubber dam in different operative and endodontic treatments. A data analysis was carried out using SPSS version 25 . A descriptive statistical analysis was done, and a Chi-square test was performed to compare the obtained data. The data evaluation was at a significant level of $p<0.05$.

Results: Out of 380 questionnaires distributed, 346 were filled and returned, the response rate was $91.05 \%$. Rubber dam was used by $91.62 \%$ of the participants $(n=317)$ on child patients. Rubber dam was never used by $47.11 \%$ of the participants $(n=163)$ when placing amalgam restorations, and by $5.50 \%$ of the participants $(n=19)$ when placing composite restorations. Rubber dam was used by $61.85 \%$ of the participants $(n=214)$ after access cavity preparation when performing root canal treatments. A total of $44.22 \%$ of the participants $(n=153)$ believed that their use of rubber dam will be in all indicated procedures after graduation.

Conclusion: Within the limits of this study, there was still a high possibility among the undergraduate dental students that they might not practice routine placement of rubber dam after graduation.

Clinical significance: A very important method to improve the clinical dental practicing is by studying how dental students looks to the details of each dental procedure, so the academic institutes can change the wrong thoughts of the future dentists from the dental student level. One of these important procedures is the rubber dam application.
\end{abstract}

Keywords: Amalgam, Dental students, Endodontics, Operative dentistry, Restoration, Rubber dam.

World Journal of Dentistry (2020): 10.5005/jp-journals-10015-1699

\section{INTRODUCTION}

Moisture control means excluding saliva, sulcular fluid, and gingival bleeding from the operation field and preventing the handpiece spray and restorative materials from being aspirated or swallowed. The creation of dryness by the exclusion of mouth sections and humidity from the operative field is essential for rightly performing most restorative procedures.

The rubber dam has many advantages in most branches of dentistry and is mandatory for legal considerations. The usage of the rubber dam is a must in recent endodontic and operative dentistry practice because it provides a clean operating field, isolating the tooth from salivary contamination, preventing the inhalation or ingestion of dental instruments and materials, ${ }^{1}$ and protecting the oral soft tissues and gingiva from contact with solutions used during dental treatments, such as sodium hypochlorite and phosphoric acids. Rubber dam decreases aerosol contamination and cross-infection by up to $98.5 \%$ if it is used during conservation procedures, $^{2-5}$ and may also reduce transmission of acquired immunodeficiency syndrome, hepatitis, and tuberculosis., ${ }^{3,6,7}$ It is made of latex, but nonlatex rubber dam sheets are available for patients with latex sensitivity. ${ }^{8}$ The use of dental dam is the standard of care. ${ }^{9,10}$ With the understanding of the basic principles and a well-qualified dental assistant, a single tooth can be isolated in only a few seconds. Many reasons have been reported for the lack of rubber dam use which include patient objection, time
${ }^{1}$ Department of Endodontics and Operative dentistry, Damascus University, College of Dentistry, Damascus, Syria

${ }^{2}$ Department of Restorative Dental Sciences, Alfarabi Colleges of Dentistry and Nursing, Riyadh, Kingdom of Saudi Arabia

${ }^{3}$ Endodontics and Operative Dentistry Department, Syrian Private University, Damascus, Syria

${ }^{4}$ Almajmaah University, Al Majma'ah, Kingdom of Saudi Arabia

${ }^{5}$ Department of Restorative Dental Sciences, Buraydah Colleges, College of Dentistry, Buraydah, Kingdom of Saudi Arabia

Corresponding Author: Mazen Doumani, Department of Restorative Dental Sciences, Alfarabi Colleges of Dentistry and Nursing, Riyadh, Kingdom of Saudi Arabia, Phone: +91 966536171211, e-mail: Mazendom@hotmail.com

How to cite this article: Younes LMF, Doumani M, Al-Nahlawi TF, et al. Syrian Senior Dental Students' Perception, Educational Satisfaction, and Attitude Regarding the Usage of Rubber Dam. World J Dent 2020;11(1):47-51.

Source of support: Nil

Conflict of interest: None

consumption, cost of materials, and shortage in training. In current cariology and endodontics, both undergraduate education in the use of rubber dam and its later practical use should belong to standard knowledge and skills. ${ }^{11}$ This study aimed to determine

(0) The Author(s). 2020 Open Access This article is distributed under the terms of the Creative Commons Attribution 4.0 International License (https://creativecommons. org/licenses/by-nc/4.0/), which permits unrestricted use, distribution, and non-commercial reproduction in any medium, provided you give appropriate credit to the original author(s) and the source, provide a link to the Creative Commons license, and indicate if changes were made. The Creative Commons Public Domain Dedication waiver (http://creativecommons.org/publicdomain/zero/1.0/) applies to the data made available in this article, unless otherwise stated. 
the perception, educational satisfaction, and attitude of dental students (fourth and fifth years) regarding their use of rubber dam.

\section{Materials and Methods}

Anonymously, a piloted questionnaire was delivered to fourth- and fifth-year dental students in Damascus (governmental) and Syrian private (private) dental schools in August 2019. Survey preparation depended on the study of Mala et al.,12 Abdulrab et al., ${ }^{13}$ and Tanalp et al. ${ }^{14}$ The pilot study was conducted on a random sample of students ( $n=15$ ) to be sure that the questions were clear. A total of 380 survey (14 questions) forms were distributed. The questions were closed ended, divided into five groups as following (demographic, utilization of rubber dam, students' opinions about the usage of rubber dam, students' opinion about the difficult sides regarding rubber dam usage, expressions of students regarding various aspects of rubber dam, and opinion of students about postgraduation usage of rubber dam). The mode of answering the questions was variable [(yes or no), (always, never, rarely, and sometimes), (I agree, I disagree)]. A data analysis were carried out using SPSS version 25. A descriptive statistical analysis was done, and a Chi-square test was performed for qualitative data comparing. Results were evaluated at a significant level of $p<0.05$.

\section{Results}

Out of 380 questionnaires, 346 were completed and returned with response rate of $91.05 \%$.

As it is shown in Table 1, 170 (49.13\%) were female respondents, whereas 176 (50.87\%) were male respondents, 80 (23.12\%) were in the fourth year, and 266 (76.88\%) in the fifth year. The majority (70.23\%) always did not ask their patients about latex allergy, with a significant statistical difference between the studied two dental school $(p<0.05)$. A total of $317(91.62 \%)$ did not use rubber dam for pediatric patients, $163(47.11 \%)$ never used it in case of amalgam restoration, but 185 (45\%) always used it with composite

Table 1: Responses to questions regarding utilization of rubber dam

\begin{tabular}{|c|c|c|c|c|c|c|c|}
\hline & \multicolumn{2}{|c|}{ Damascus university } & \multicolumn{2}{|c|}{ Syrian private university } & \multicolumn{2}{|c|}{ Total } & \multirow[b]{2}{*}{ Significance } \\
\hline & Frequency & Percentage & Frequency & Percentage & Frequency & Percentage & \\
\hline \multicolumn{8}{|l|}{ Gender } \\
\hline Male & 95 & 43.2 & 81 & 64.3 & 176 & 50.87 & $\chi^{2}=14.277$ \\
\hline Female & 125 & 56.8 & 45 & 35.7 & 170 & 49.13 & $p=0.0002$ \\
\hline \multicolumn{8}{|l|}{ Academic year } \\
\hline Fourth & 35 & 15.9 & 45 & 35.7 & 80 & 23.12 & $\chi^{2}=17.679$ \\
\hline Fifth & 185 & 84.1 & 81 & 64.3 & 266 & 76.88 & $p=0.00001$ \\
\hline \multicolumn{8}{|c|}{ Do you ask your patients whether they have latex allergy prior to rubber dam use? } \\
\hline Yes & 54 & 42.5 & 49 & 38.9 & 103 & 29.77 & $\chi^{2}=7.884$ \\
\hline No & 166 & 75.5 & 77 & 61.1 & 243 & 70.23 & $p=0.005$ \\
\hline \multicolumn{8}{|l|}{ Do you use rubber dam in pediatric patients? } \\
\hline Yes & 202 & 91.8 & 115 & 91.3 & 317 & 91.62 & $\chi^{2}=0.031$ \\
\hline No & 18 & 8.2 & 11 & 8.7 & 29 & 8.38 & $p=0.859$ \\
\hline \multicolumn{8}{|l|}{ Do you use rubber dam during amalgam restorations? } \\
\hline Always & 6 & 2.7 & 10 & 7.9 & 16 & 4.62 & $\chi^{2}=5.356$ \\
\hline Never & 104 & 47.3 & 59 & 46.8 & 163 & 47.11 & $p=0.148$ \\
\hline Rarely & 36 & 16.4 & 21 & 16.7 & 57 & 16.47 & \\
\hline Sometimes & 74 & 33.6 & 36 & 28.6 & 110 & 31.80 & \\
\hline \multicolumn{8}{|c|}{ Do you use rubber dam during composite restorations? } \\
\hline Always & 99 & 45 & 86 & 68.3 & 185 & 53.47 & $\chi^{2}=17.647$ \\
\hline Never & 15 & 6.8 & 4 & 3.2 & 4 & 3.2 & $p=0.001$ \\
\hline Rarely & 7 & 3.2 & 3 & 2.4 & 3 & 2.4 & \\
\hline Sometimes & 99 & 45 & 33 & 26.1 & 33 & 26.2 & \\
\hline \multicolumn{8}{|c|}{ During which stage of endodontic treatment do you use rubber dam? } \\
\hline After access cavity preparation & 143 & 65 & 71 & 56.3 & 214 & 61.85 & $\chi^{2}=11.448$ \\
\hline Before access cavity preparation & 51 & 23.2 & 48 & 38.1 & 99 & 28.61 & $p=0.022$ \\
\hline During root canal cleaning and shaping only & 7 & 3.2 & 3 & 2.4 & 10 & 2.90 & \\
\hline During root canal filling only & 19 & 8.6 & 4 & 3.2 & 23 & 6.65 & \\
\hline \multicolumn{8}{|c|}{ Do you think you have been given adequate and satisfactory education regarding rubber dam? } \\
\hline Yes & 106 & 48.2 & 62 & 49.2 & 168 & 48.55 & $\chi^{2}=0.034$ \\
\hline No & 114 & 51.8 & 64 & 50.8 & 178 & 51.45 & $p=0.854$ \\
\hline \multicolumn{8}{|c|}{ During endodontic treatment of teeth with extensive tissue loss } \\
\hline I don't use rubber dam & 147 & 66.9 & 66 & 52.4 & 213 & 61.56 & $\chi^{2}=7.473$ \\
\hline $\begin{array}{l}\text { I perform a restoration so that I can place the } \\
\text { rubber dam }\end{array}$ & 73 & 33.1 & 60 & 47.6 & 133 & 38.44 & $p=0.024$ \\
\hline
\end{tabular}


Table 2: Opinions of students about the usage of rubber dam

\begin{tabular}{|c|c|c|c|c|c|c|c|}
\hline & \multicolumn{2}{|c|}{ Damascus university } & \multicolumn{2}{|c|}{ Syrian private university } & \multicolumn{2}{|c|}{ Total } & \multirow[b]{2}{*}{ Significance } \\
\hline & Frequency & Percentage & Frequency & Percentage & Frequency & Percentage & \\
\hline \multicolumn{8}{|c|}{ What in your opinion is the greatest advantage offered by the rubber dam? } \\
\hline Prevention of ingestion of irrigant & 15 & 6.8 & 15 & 11.9 & 30 & 8.67 & $\chi^{2}=21.183$ \\
\hline $\begin{array}{l}\text { Prevention of swallowing or aspirating } \\
\text { instruments }\end{array}$ & 14 & 6.4 & 14 & 11.1 & 28 & 8.09 & $p=0.0001$ \\
\hline Provision of isolation and an aseptic working area & 191 & 86.8 & 97 & 76.98 & 288 & 83.24 & \\
\hline
\end{tabular}

Table 3: Students' opinion about the most difficult aspect regarding rubber dam usage

\begin{tabular}{|c|c|c|c|c|c|c|c|}
\hline & \multicolumn{2}{|c|}{ Damascus university } & \multicolumn{2}{|c|}{ Syrian private university } & \multicolumn{2}{|c|}{ Total } & \multirow[b]{2}{*}{ Significance } \\
\hline & Frequency & Percentage & Frequency & Percentage & Frequency & Percentage & \\
\hline \multicolumn{8}{|c|}{ What is the major factor that makes rubber dam application a difficult procedure? } \\
\hline Placemen of the frame & 10 & 4.5 & 2 & 1.6 & 12 & 3.47 & $\chi^{2}=11.805$ \\
\hline Placement of the rubber dam & 34 & 15.5 & 38 & 30.2 & 72 & 20.81 & $p=0.003$ \\
\hline Selection of the clamp and its adaptation & 176 & 80 & 86 & 68.3 & 262 & 75.72 & \\
\hline
\end{tabular}

Table 4: Agreement or disagreement of students regarding various aspects of rubber dam

\begin{tabular}{|c|c|c|c|c|c|c|c|}
\hline & \multicolumn{2}{|c|}{ Damascus university } & \multicolumn{2}{|c|}{ Syrian private university } & \multicolumn{2}{|c|}{ Total } & \multirow[b]{2}{*}{ Significance } \\
\hline & Frequency & Percentage & Frequency & Percentage & Frequency & Percentage & \\
\hline \multicolumn{8}{|c|}{ Rubber dam eases the restoration stage } \\
\hline I agree & 172 & 78.2 & 94 & 74.6 & 266 & 76.87 & $\chi^{2}=0.577$ \\
\hline I disagree & 48 & 21.8 & 32 & 25.4 & 80 & 23.13 & $p=0.447$ \\
\hline \multicolumn{8}{|c|}{ Treatment performed using the rubber dam are more successful than those performed without using it } \\
\hline I agree & 194 & 88.2 & 112 & 88.9 & 306 & 88.44 & $\chi^{2}=0.039$ \\
\hline I disagree & 26 & 11.8 & 14 & 11.1 & 40 & 11.56 & $p=0.843$ \\
\hline \multicolumn{8}{|c|}{ An adequate isolation cannot be achieved in case of rubber dam is not used } \\
\hline I agree & 117 & 53.2 & 84 & 66.7 & 201 & 58.1 & $\chi^{2}=5.984$ \\
\hline I disagree & 103 & 46.8 & 42 & 33.3 & 145 & 41.9 & $p=0.014$ \\
\hline \multicolumn{8}{|c|}{ Rubber dam eases access to root canals } \\
\hline I agree & 125 & 56.8 & 72 & 57.1 & 197 & 56.9 & $\chi^{2}=0.003$ \\
\hline I disagree & 95 & 43.2 & 54 & 42.9 & 149 & 43.1 & $p=0.953$ \\
\hline \multicolumn{8}{|c|}{ Rubber dam makes radiograph-taking procedure difficult } \\
\hline I agree & 197 & 89.5 & 115 & 91.3 & 312 & 90.12 & $\chi^{2}=0.269$ \\
\hline I disagree & 23 & 10.5 & 11 & 8.7 & 24 & 9.88 & $p=0.604$ \\
\hline \multicolumn{8}{|c|}{ Rubber dam is difficult to apply } \\
\hline I agree & 91 & 41.4 & 63 & 50 & 154 & 44.51 & $\chi^{2}=2.419$ \\
\hline I disagree & 129 & 58.6 & 63 & 50 & 192 & 55.49 & $p=0.120$ \\
\hline \multicolumn{8}{|c|}{ Rubber dam consists of too many components } \\
\hline I agree & 98 & 44.5 & 64 & 50.8 & 162 & 46.8 & $\chi^{2}=1.256$ \\
\hline I disagree & 122 & 55.5 & 62 & 49.2 & 184 & 53.2 & $p=0.262$ \\
\hline \multicolumn{8}{|c|}{ Rubber dam extends treatment period } \\
\hline I agree & 100 & 45.5 & 66 & 52.4 & 166 & 47.98 & $\chi^{2}=1.540$ \\
\hline I disagree & 120 & 54.5 & 60 & 47.6 & 180 & 52.02 & $p=0.215$ \\
\hline \multicolumn{8}{|c|}{ Rubber dam is more necessary while working in the maxillary teeth } \\
\hline I agree & 16 & 7.3 & 23 & 18.3 & 39 & 11.3 & $\chi^{2}=9.660$ \\
\hline I disagree & 204 & 92.7 & 103 & 81.7 & 307 & 88.7 & $p=0.002$ \\
\hline \multicolumn{8}{|c|}{ Assistance is necessary during rubber dam application } \\
\hline I agree & 148 & 67.3 & 80 & 63.5 & 228 & 65.9 & $\chi^{2}=0.510$ \\
\hline I disagree & 72 & 32.7 & 46 & 36.5 & 118 & 34.1 & $p=0.475$ \\
\hline \multicolumn{8}{|c|}{ Patients do not like the rubber dam } \\
\hline I agree & 202 & 91.8 & 116 & 92.1 & 318 & 91.9 & $\chi^{2}=0.006$ \\
\hline I disagree & 18 & 8.2 & 10 & 7.9 & 28 & 8.1 & $p=0.936$ \\
\hline \multicolumn{8}{|c|}{ I only use rubber dam because I am obliged to following graduation } \\
\hline I agree & 106 & 48.2 & 61 & 48.4 & 167 & 48.27 & $\chi^{2}=0.002$ \\
\hline I disagree & 114 & 51.8 & 65 & 51.6 & 179 & 51.73 & $p=0.967$ \\
\hline
\end{tabular}


The Usage of Rubber Dam among Syrian Dental Students

\begin{tabular}{|c|c|c|c|c|c|c|c|}
\hline & \multicolumn{2}{|c|}{ Damascus university } & \multicolumn{2}{|c|}{ Syrian private university } & \multicolumn{2}{|c|}{ Total } & \multirow[b]{2}{*}{ Significance } \\
\hline & Frequency & Percentage & Frequency & Percentage & Frequency & Percentage & \\
\hline \multicolumn{8}{|l|}{ Following graduation: } \\
\hline $\begin{array}{l}\text { I intend to use it only during restorative } \\
\text { procedures }\end{array}$ & 7 & 3.2 & 8 & 6.3 & 15 & 4.34 & $\chi^{2}=8.324$ \\
\hline I intend to use it only during root canal treatment & 89 & 40.4 & 41 & 32.5 & 130 & 37.57 & $p=0.040$ \\
\hline $\begin{array}{l}\text { I intend to use the rubber dam during all } \\
\text { procedures indicated }\end{array}$ & 88 & 40 & 65 & 51.6 & 153 & 44.21 & \\
\hline I will never use it & 36 & 16.4 & 12 & 9.5 & 48 & 13.9 & \\
\hline
\end{tabular}

restoration ( $p<0.05)$. A total of $214(61.85 \%)$ of the students used to apply rubber dam after access cavity preparation $(p<0.05)$. A total of 178 (51.45\%) of the students did not take an adequate education regarding the use of rubber dam. Furthermore, 213 $(61.56 \%)$ never used rubber dam during working on teeth with large tissue loss $(p<0.05)$.

The most important advantage for rubber dam was creating isolation and an aseptic field as reported by $83.24 \%$ of the participants ( $p<0.05$; Table 2 ). Most of the students $(262,75.72 \%)$ reported that choosing the clamp and its adaptation was the most difficult stage of rubber dam usage ( $p<0.05$; Table 3 ).

Table 4 summarizes agreements or disagreements of students toward different aspects of rubber dam. The Chi-square test revealed that no statistically significant effect was present among responses in Table 4 except for the inability to establish an adequate isolation without using rubber dam and the opinion about rubber dam is more necessary in maxillary teeth $(p<0.05)$. Table 5 shows the opinions about the postgraduation usage of rubber dam. A total of $153(44.22 \%)$ of the students intended that following graduation, they will use rubber dam for all the procedures indicated $(p<0.05)$.

\section{Discussion}

The goal of recent dental schools is to introduce well-qualified dentists on graduation. This is a challenge because of huge number of students and dental schools, and decreased numbers of qualified dental educators. ${ }^{15,16}$ Almost all dental schools teach the students that the use of rubber dam is obligatory for most restorative treatments in children and adults. ${ }^{11}$ So, this will have a significant positive effect on its usage after graduation. A total of $70.23 \%$ of the students in the recent study did not investigate latex allergy among their patients; this percentage is higher than in Abdulrab et al.'s study ${ }^{13}$ and Tanalp et al.'s study. ${ }^{14}$ This means proper orientation of students should be present to focus on the possibility of latex allergy prior to application of the rubber. ${ }^{17}$ A high number of students (317, $91.62 \%$ ) do not use rubber dam in pedodontic patients, which is close percentage to some previous studies. ${ }^{13,14}$ A total of $47.11 \%$ never used rubber dam in cases of amalgam restoration as in Akbar et al. ${ }^{18}$ but higher than the result of Abdulrab et al. ${ }^{13}$ However, the results regarding the use of rubber dam with composite restoration were compatible with Tanalp et al. ${ }^{14}$ Only $28.61 \%$ of the students apply rubber dam before access cavity preparation in root canal treatment; this value is low when compared with other studies. ${ }^{13,19}$ Approximately $50 \%$ of the respondents declared that they did not have adequate and satisfactory education regarding rubber dam as in the study of Akbar et al. ${ }^{18}$ and Al-Haj Ali et al. ${ }^{20}$ The majority of students in this study preferred not to use rubber dam when a tooth was with extensive tissue loss agreeing with Tanalp et al., ${ }^{14}$ and this could be explained by the fact that large loss of tooth structure may cause a difficulty in adapting a regular clamp. The greatest advantage gained from rubber dam from the students' point of view (83.24\%) was to perform suitable isolation and an aseptic field, and this is similar to Abdulrab et al.'s study. The most difficult step in the rubber dam application was clamp choosing and application (75.72\%), while in other studies (Abdulrab et al. and Tanalp et al.), this reached $73 \%$ and $84 \%,{ }^{13,14}$ respectively. This may be because students may not have adequate sizes and types of clamps, suitable for different cases as students in these schools buy the instruments by themselves. A total of $77 \%$ of the students in this study agreed that rubber dam eases restoration stage, and this result matches with that of Akbar et al. ${ }^{18}$ The majority of our students agreed that rubber dam allows a more successful treatments, a result which is consistent with many studies. ${ }^{13,14,18}$ A total of $58 \%$ of the students felt that intended isolation cannot be found without rubber dam application comparing with high percentages of other studies. ${ }^{21}$ Rubber dam makes it easy to access the root canals; this thought were supported by $56.9 \%$ of the contributors, which is slightly more than the response in Tanalp et al.'s study. ${ }^{14}$ It is difficult to take a radiograph in the suitable position with the dam in place, and this is another disadvantage as reported by $90 \%$ of the students, and it is known that removing rubber dam during radiography is an accepted behavior as this step is performed with an instrument within the root canal, and the patient generally stays alone in the X-ray room. In this study, around $44.51 \%$ of the respondents agreed that dental dam is difficult to apply; a similar finding has been reported by Abdulrab et al. ${ }^{13}$ About half of the study sample reported that the too much components of rubber dam disturb them, but this percentage is still the lowest when compared with other studies. ${ }^{13,14,18}$ The majority (91.9\%) of students went with the statement "Patients do not like the rubber dam," so this is contradictory to the dental literature. ${ }^{22,23}$ Dental students may show ideal views about recent methodologies upon graduation; $48.27 \%$ of the students reported that they apply rubber dam only because they are obliged to following graduation, so additional efforts should be made to change this mistaken thoughts about the importance of rubber dam in safety measures in dental practice by showing students the happened accidents from ignoring the usage of dental dam and aftermath. ${ }^{14}$ Another study should be conducted to evaluate the efficacy of teaching plan modification.

\section{ConClusion}

Within the limits of this study

- Efforts should be paid to assure dental students to ask their patients about latex energy. 
- Dental student should be oriented to use rubber dam in pediatric dentistry.

- It is necessary to persuade the students of the importance of rubber dam application in different procedures including amalgam and composite restoration, and this will guarantee the use of it after graduation.

- Providing suitable and impressive education regarding rubber dam usage should be revised in the syllabuses of the studied two colleges.

\section{References}

1. Huggins DR. The rubber dam: an insurance policy against litigation. J Indiana Dent Assoc 1986;65(3):23-24.

2. Marshall K. Dental workspace contamination and the role of rubber dam. CPD Dent 2001;2(2):48-50.

3. Forrest WR, Perez RS. AIDS and hepatitis prevention: the role of the rubber dam. Oper Dent 1986;11(4):159.

4. Cochran MA, Miller $\mathrm{CH}$, Sheldrake MA. The efficacy of the rubber dam as a barrier to the spread of microorganisms during dental treatment. J Am Dent Assoc 1989;119(1):141-144. DOI: 10.14219/jada. archive.1989.0131.

5. Samaranayake LP, Reid J, Evans D. The efficacy of rubber dam isolation in reducing atmospheric bacterial contamination. ASDC J Dent 1989;56(6):442-444.

6. Miller RL, Micik RE. Air pollution and its control in the dental office. Dent Clin North Am 1978;22:453-476.

7. Wong RC. The rubber dam as a means of infection control in an era of AIDS and hepatitis. J Indiana Dent Assoc 1988;67:41-43.

8. De Andrade ED, Ranali J, Volpato MC, et al. Allergic reaction after rubber dam placement. J Endod 2000;26(3):182-183. DOI: 10.1097/00004770-200003000-00014.

9. The Dentist Insurance Company, California Dental Association. Rubber dam it. Liability Lifeline 2004;80:1-7.

10. Loest C. Quality guidelines for endodontic treatment: consensus report of the European Society of Endodontology. Int Endod J 2006;39(12):921-930.
11. Ryan W, O'Connell A. The attitudes of undergraduate dental students to the use of the rubber dam. J Ir Dent Assoc 2007;53(2): 87-91.

12. Mala S, Lynch CD, Burke FM, et al. Int Endod J 2009;42(7):632-638. DOI: 10.1111/j.1365-2591.2009.01569.x.

13. Abdulrab S, Al-Maweri SA, Doumani M, et al. Rubber dam: attitudes and practices of senior dental students in Saudi Arabia. IOSR Journal of Dental and Medical Sciences 2016;15(2):79-83.

14. Tanalp J, Kayataş M, Başer Can ED, et al. Evaluation of senior dental students' general attitude towards the use of rubber dam: a survey among two dental schools. Sci World J 2014. 1-8. DOI: 10.1155/2014/290101.

15. Wilson NHF. Curricular issues changing from amalgam to toothcolored materials. J Dent 2004;32(5):367-369.

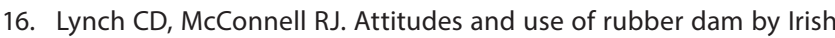
general dental practitioners. Int Endod J 2007;40:427-432. DOI: 10.1111/j.1365-2591.2007.01212.x.

17. Kleier DJ, Shibilski K. Management of the latex hypersensitive patient in the endodontic office. J Endod 1999;25(12):825-828. DOI: 10.1016/ S0099-2399(99)80307-0.

18. Akbar I, Alam F, Qureshi B, et al. The attitude of undergraduate dental students toward the use of rubber dam. Pak Oral Dent $J$ 2017;37(4):622-627.

19. Csinszka K-IA, Monica M, Mihai $P$, et al. Prevalence of rubber dam usage among dental practitioners and final year students in tirgu mures: a questionnaire survey. Acta Med Marisiensis 2015;61(3): 189-191. DOI: 10.1515/amma-2015-0059.

20. Al-Haj Ali SN, Al-Mohaimeed BA. The attitude of undergraduate dental students toward the use of rubber dam in College of dentistry, Qassim University. Int J Adv Res 2015;3(11):1480-1485.

21. Al-Sabri FA, Elmarakby AM, Hassan AM. Isolation in operative field. Eur J Dent 2017;11(1):83-88.

22. Feierabend SA, Matt J, Klaiber B. Comparison of conventional and new rubber dam systems in dental practice. Oper Dent 2011;36(3):243-250. DOI: 10.2341/09-283-C.

23. Stewardson DA, McHugh ES. Patient's attitudes to rubber dam. Int Endod J 2002;35(10):812-819. DOI: 10.1046/j.1365-2591.2002. 00571.x. 